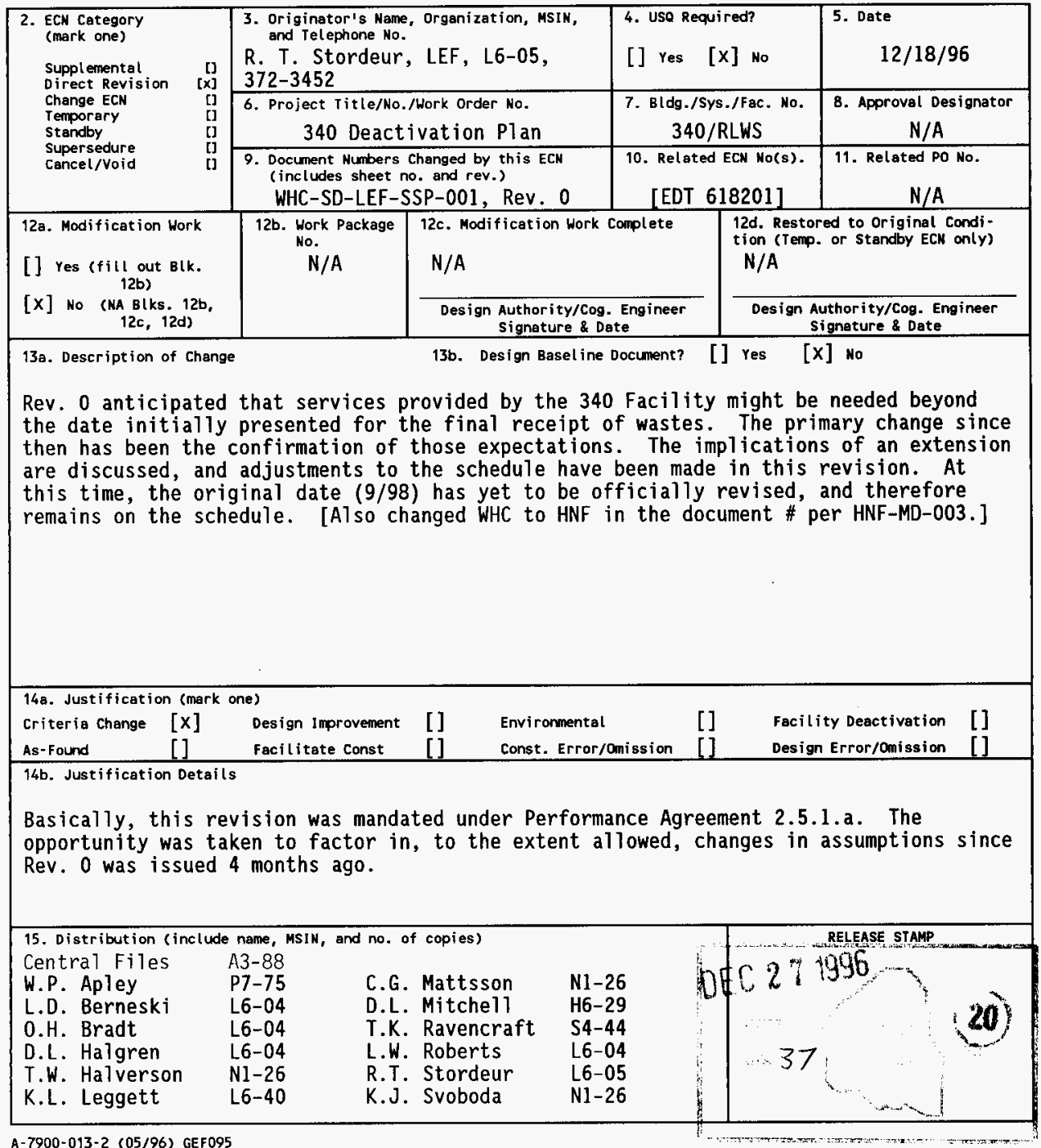




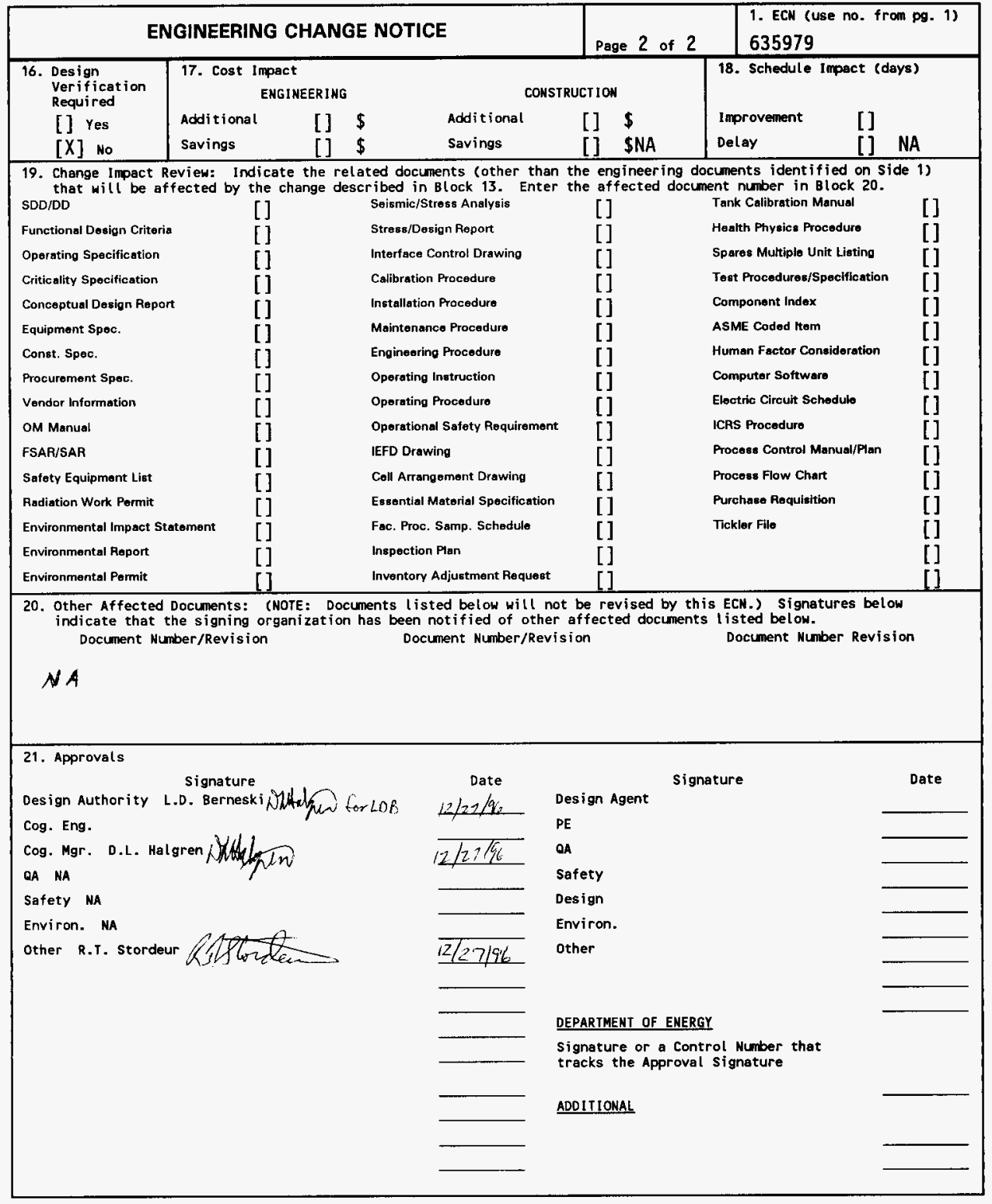




\title{
340 Waste Handling Facility Deactivation Plan
}

\author{
R.T. Stordeur, L.D. Berneski
}

Rust Federal Services of Hanford Inc., Richland, WA 99352

U.S. Department of Energy Contract DE-AC06-96RL13200

ECN: 635979

Org Code: 32330

UC: 2050

B\&R Code: EW3130020

Charge Code: A234C

Total Pages: 33

Key Words: 340 Facility, radioactive liquid waste system, RLWS, retention process sewer, RPS, 307 basins, waste storage tanks, 300 Area, deactivation, shut-down, decommissioning, transition.

Abstract: This document provides an overview of both the present status of the 340 Complex (within Hanford's 300 Area), and of tasks associated with the deactivation of segments associated with radioactive, mixed liquid waste receipt, storage, and shipping. The plan also describes activities that will allow portions of the 340 Complex to remain in service.

TRADEMARK DISCLAIMER. Reference herein to any specific commercial product, process, or service by trade name, trademark, manufacturer, or otherwise, does not necessarily constitute or imply its endorsement, recommendation, or favoring by the United States Government or any agency thereof or its contractors or subcontractors.

Printed in the United States of America. To obtain copies of this document, contact: WHC/BCS Document Control Services, P.O. Box 1970, Mailstop H6-08, Richland WA 99352, Phone (509) 372-2420; Fax (509) $376-4989$
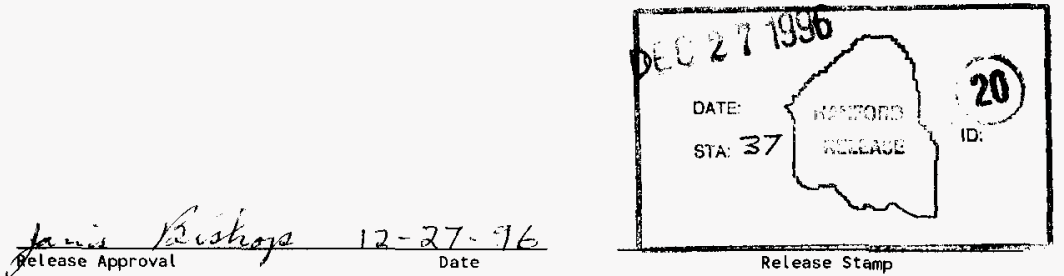

\section{Approved for Public Release}




\section{RECORD OF REVISION}

(1) Document Number

HNF-SD-LEF-SSP001

Page 1

(2) Title

340 Waste Handling Facility Deactivation Plan

CHANGE CONTROL RECORD

\begin{tabular}{|c|c|}
\hline (3) Revision & (4) Description of Change - Repiace, Add, and Delete Pages \\
\hline 0 & $\begin{array}{l}\text { (7) Original Issue }(8 / 20 / 96 \text { release, EDT \# } \\
618201)\end{array}$ \\
\hline 1 RS & $\begin{array}{l}\text { Required revision, complete replacement } \\
\text { (ECN \#635979) }\end{array}$ \\
\hline
\end{tabular}

Authorized for Release

(5) Cog. Engr. (6) Cog. Mgr. Date

LD Berneski DL Halgren

[Signed

$8 / 20 / 96$

Original]

[Signed

original]

LD Berneski DL Halgren

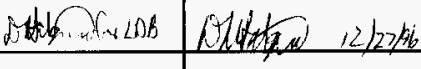




\title{
340 Waste Handling Facility Deactivation Plan
}

\author{
HNF-SD-LEF-SSP-001 \\ Rev. 1
}

\author{
L.D. Berneski, R.T. Stordeur \\ 300 Area Liquid Effluent Process Engineering
}

December 1996 
HNF-SD-LEF-SSP-001, Rev. I

\section{EXECUTIVE SUMMARY}

The 340 Complex provides radioactive, mixed liquid waste storage and transfer services for several 300 Area facilities. The Department of Energy - Richland operations office (RL) has requested an update of the existing plan (Rev 0 of this document) to deactivate the radioactive liquid waste system (RLWS) portions of the 340 Complex. The original (Rev 0 ) planning dates have not been officially modified, with the September 1998 end-date for new RLWS waste receipts of immediate interest. However, recent indications from Babcock \& Wilcox Hanford (B\&W) are that the deactivation of the 324 and 327 laboratories might require an active 340 Facility beyond that date. Therefore, this revision attempts to explore some of the implications of a delayed 340 deactivation, without making any major adjustments to the original time-line.

The time period of primary interest is still from the present until 340 facility systems are terminated and stabilized. The potential B\&W need for 340 , along with funding shortfalls for some of the upgrades required to meet September $1998^{1}$, combine to challenge the realization of that goal from both suitability and feasibility standpoints. Upon reaching agreement on a new date for ending waste receipts at the vault, September 30, 1998 can be dropped from the schedule.

The following activities are recommended (not necessarily chronological):

- Work with all interested parties to determine a realistic shutdown timetable. Make a final revision to this $p l a n$ if deactivation is postponed for many years, otherwise proceed directly to the next task;

- Prepare a project management plan (PMP) with detailed work breakdown structure, budget and schedule;

- Negotiate satisfactory "end points" with the receiving caretaker, for the condition of areas, structures, and equipment at the time of transfer; and,

- Perform these specific tasks:

* Implement a run-to-fail policy for non essential equipment/systems,

1 Such as providing capabilities both for waste storage and load-out at the 325 laboratory, and for accepting specific trucks at the 204-AR waste receiving facility (collectively under Project $0-472$ ). 


\section{HNF-SD-LEF-SSP-001, Rev. 1}

* Inspect and clean-out $340-\mathrm{A}$, the 340 decontamination area, the 340 vault/tanks and upstream RLWS components, and finally the 340-B loadout facility,

* De-couple the Retention Process Sewer system from RLWS system, and

* Conceptualize/implement upgrades needed to facilitate surveillance \& maintenance phase (e.g., modify lighting/electrical service, install remote surveillance systems, minimize HVAC, weatherize buildings, relocate alarms).

A rough schedule summarizing these activities is provided. The final version of this plan and/or the PMP recommended above will document further details and reflect the impact of any additional changes to the assumptions (e.g., in railroad availability, lab missions, waste volumes, regulations) that might significantly alter projections. Excluded from the schedule are projects outside Rust Federal Service Hanford's jurisdiction; such as the previously mentioned modifications to both 325 and 204-AR that respectively fall under the domain of Pacific Northwest National Laboratory and Lockheed Martin Hanford Company. 


\section{HNF-SD-LEF-SSP-001, Rev. 1}

\section{Table of Contents}

EXECUTIVE SUMMARY . . . . . . . . . . . . . . . . . . . . . i i

ABBREVIATIONS/ACRONYMS LIST . . . . . . . . . . . . . . . . . V v

1.0 OVERVIEW . . . . . . . . . . . . . . . . . . . . . . . 1

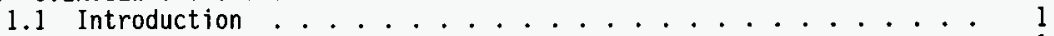

1.2 Assumptions . . . . . . . . . . . . . . . . . . . . 1

2.0 CURRENT CONDITIONS ............................... 3

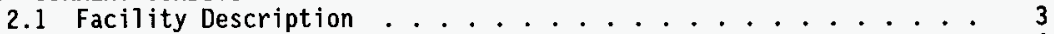

2.2 Organization and Control ................ . . 4

2.3 Environmental Compliance ................ . . 5

2.4 Safety ..................... . . . 6

3.0 DEACTIVATION STRATEgY . . . . . . . . . . . . . . . . . 8

3.1 Near Term Actions . . . . . . . . . . . . . . . . 8

3.1.1 340 Facility Mission . . . . . . . . . . . . . . 8

3.1.2 Impacts of extended 340 0perations . . . . . . . . . . 8

3.2 Interim 0perations ................... . . . 9

3.2.1 SSC Related .................... . . 9

3.2.2 Management Related ................... . . . 11

3.3 Facility Stabilization Actions . . . . . . . . . . . 12

3.3.1 Inventory Description ............... . . 12

3.3.2 Inventory Reduction Actions . . . . . . . . . . . 14

3.4 De-coupling RPS from RLWS . . . . . . . . . . . . . . 15

3.4.1 Changes to Diverters and Associated Operational Controls . . 16

3.4.2 Truck Load-out Station . . . . . . . . . . . . . . . 16

3.4.3 Stand-by Treatment . . . . . . . . . . . . . . . . . . . . . 17

3.5 Interim maintenance \& surveiliance . . . . . . . . . . . 17

4.0 SUMMARY SCHEDULE . . . . . . . . . . . . . . . . . . . . . . 19

5.0 REFERENCES .......................... . . 21

Appendix A Overview of deactivation process . . . . . . . . . . . . . 24

\section{List of Figures}

Figure 4-1 Summary Schedule . . . . . . . . . . . . . . . . 20

Figure A-1 Generic Decommissioning Process................ 25 
HNF-SD-LEF-SSP-001, Rev. 1

ABBREVIATIONS/ACRONYMS LIST

$\begin{array}{ll}\text { AGS } & \text { above ground storage } \\ \text { ALARA } & \text { as low as reasonably achievable } \\ \text { BIO } & \text { basis for interim operation } \\ \text { B\&W } & \text { Babcock \& Wilcox Hanford Company } \\ \text { CFR } & \text { code of federal regulations } \\ \text { CX } & \text { categorical exclusion (NEPA) } \\ \text { D\&D } & \text { decontamination and decommissioning } \\ \text { DOE } & \text { U.S. Department of Energy } \\ \text { DPM } & \text { disintegrations per minute } \\ \text { EA } & \text { environmental assessment (NEPA) } \\ \text { ECOlogy } & \text { State of Washington Department of Ecology } \\ \text { EPA } & \text { U.S. Environmental Protection Agency } \\ \text { EPC } & \text { end-point criteria } \\ \text { ER } & \text { Environmental Restoration } \\ \text { ERDA } & \text { U. S. Energy Research and Development Agency } \\ \text { FDH } & \text { Fiur Danie1 Hanford, Inc. } \\ \text { HEPA } & \text { high efficiency particulate air [filter] } \\ \text { HQ } & \text { [DOE] Headquarters } \\ \text { HVAC } & \text { heating, ventilating, and air conditioning } \\ \text { ISB } & \text { interim safety basis } \\ \text { LEF } & \text { Liquid Effluent Facilities } \\ \text { LMHC } & \text { Lockheed Martin Hanford Co. } \\ \text { MCM } & \text { minimum critical mass } \\ \text { MYPP } & \text { multi-year program plan } \\ \text { NEPA } & \text { National Environmental Policy Act } \\ \text { NOC } & \text { notice of construction } \\ \text { PNNL } & \text { Pacific Northwest National Laboratories } \\ \text { PHMC } & \text { project Hanford management contractor } \\ \text { PM } & \text { preventive maintenance } \\ \text { PMP } & \text { project management plan } \\ \text { PS } & \text { process sewer } \\ \text { RCRA } & \text { Resource Conservation and Recovery Act } \\ \text { RCT } & \text { radiological control technician } \\ \text { RFSH } & \text { Rust Federal Services of Hanford, Inc. } \\ \text { RL } & \text { [DOE-] Richland Field office } \\ \text { RLWS } & \text { radioactive liquid waste system } \\ \text { RPS } & \text { retention process sewer } \\ \text { SAR } & \text { safety analysis report } \\ \text { S\&M } & \text { surveillance and maintenance } \\ \text { SSC } & \text { systems, structures, and components } \\ \text { TCO } & \text { terminal clean-out } \\ \text { TEDF } & \text { Treated Effluent Disposal Facility } \\ \text { TPA } & \text { Hanford Federal Facility Agreement and Consent Order } \\ \text { WDOH } & \text { Washington Department of Health } \\ \text { WHC } & \text { Westinghouse Hanford Company } \\ & \end{array}$


HNF-SD-LEF-SSP-001, Rev. 1

\subsection{OVERVIEW}

\subsection{Introduction}

The existing 340 Complex serves several 300 Area facilities which generate radioactively contaminated liquid wastes, some of which are also contaminated with hazardous materials. Wastes can be transferred to the 340 Facility storage tanks by one of four routes: 1) direct from the radioactive liquid waste system (RLWS), the primary path; 2) via tanker trucks or drums; 3) via transfers from the 307 basins; or, 4) through diversions from the retention process sewer (RPS). The RLWS portion of the facility is classified as a nonreactor category III nuclear facility, while the RPS/307 basins are nonnuclear. Section 2.1 provides more detail on these systems.

The need for this plan was initiated by the high cost associated with bringing the 340 waste tank system into compliance with RCRA tank containment requirements and in improving system maintainability, along with changing missions for the waste generators. Revision 0 presented Pacific Northwest National Laboratory (PNNL) plans to modify the 325 Laboratory to provide a self-contained waste storage and truck-based load-out/shipment system. This 325 capability, and the associated upgrades to the 204-AR waste receiving station, plus the gradual phase-out of other facilities serviced by 340 , were to allow the termination of 340 radioactive 1 iquid waste receipt operations in the near future (September 1998). Funding delays/priorities can impact these activities, although [theoretically] if funds are authorized by the end of February 1997, the aforementioned Project D-472 activities can be completed in time to support the September 1998 date (PNNL 1996d).

The process of deactivating the 340 Facility cannot begin in earnest until a service life is clearly established. Once begun, deactivation will proceed under RFSH until 340 is transferred to either the transition projects or environmental restoration contractor. This $\mathrm{plan}$ provides a list of guiding assumptions, a portrait of current operations, and a preliminary blueprint for deactivation. The objective of deactivation is to reduce physical risks and hazards; placing the facility in a passive/safe state such that the costs of both near and long-term surveillance and monitoring (S\&M) are minimized. Appendix $A$ outlines some of activities associated with the overall decommissioning process.

\subsection{Assumptions}

The baseline assumptions for this plan include:

a) Generating facilities will cease discharging wastes to the RLWS by the end of September 1998 (per RL 1996 and PNNL 1996a); and funding is available for modifications at 325/204-AR. As noted elsewhere in this plan, there have been indications (PNNL 1996b, 1996c, and 1996d) that a later date may be more appropriate, primarily to provide waste disposal services for the deactivation of the 324 and 327 laboratories. RFSH will work with B\&W and PNNL, through FDH and RL, to reach a consensus on a new date. However, the schedule in this revision of the $p l a n$ remains tied to the "official" September 1998 date. 
b) The Hanford rail system will operate as long as 340/RLWS remains viable and until waste generated by the eventual terminal clean-out of 340 facilities can be shipped out of 340-B.

c) Deactivation will be defined as activities associated with removing facility systems and/or areas from operational service with the intent of being ready for facility transition to either convert the facility for another use or move to permanent shutdown.

d) A formal "shutdown decision" will document DOE-HQ determination that the 340 Facility is surplus and has no further identified programmatic use.

e) Regulators allow for continued interim 340 operation as is. Should an extension beyond September 1998 be resolved, some upgrades to 340 are likely to be required, to validate this assumption.

f) The final waste shipment from 340 to 204-AR can occur within 2 years following the end date for new waste receipts, accommodating the terminal clean-out (TCO) phase at 340-A, 340, and 340-B.

g) After TCO and facility isolation, the hazard classification for 340 will change from category 3 to "Other Industrial Facility".

h) RFSH continues to operate the RPS/307 basin system, independent of 340 and RLWS termination, until such time RPS effluents cease.

i) 204-AR is modified to accept the LR-56 truck and/or PNNL's "bowling Ball" casks when needed.

j) Cost reductions (e.g., staff or utilities) that relate to the termination of operations will be off-set during the deactivation period by activities such as isolation, clean-out, and maintenance. This, plus the fact that the RPS/307 side continues to function, means no significant decreases should be anticipated in the annual O\&M cost until the entire complex is turned-over for long term surveillance.

k) No decontamination and decommissioning (D\&D) nor environmental restoration of existing facilities or piping is warranted under the scope of this plan. Any waste piping systems that are removed from service shall be isolated in an environmentally acceptable manner. There are no significant operational surplus/excess materials for transfer or disposal.

1) Future changes in DOE orders will not significantly alter the means for carrying out this plan.

m) To minimize worker disruption and accommodate the parallel continuation of operations at the RPS $/ 307$ basins, existing 340 Facility operations and supporting personnel will cover the basic deactivation work in addition to activities required for normal operation. Matrixed support from the transition projects organization will be sought as appropriate.

n) Partial facility turn-over (e.g., if 340-B west or portions of 340 were kept to support continuing RPS/307 operations) to either the transition projects or environmental restorations contractor might be negotiable. 


\section{HNF-SD-LEF-SSP-001, Rev. 1}

\subsection{CURRENT CONDITIONS}

This section briefly describes present conditions, such as the current 340 Facility status related to physical plant, configuration control, management organization, and safety basis. Section 3.0 subsequently addresses proposed operational or physical modifications related to the shutdown at 340 .

\subsection{Facility Description}

The following provides a summary of the buildings within the 340 facility and associated liquid waste distribution piping systems. The 340 Complex includes the 340, 340-A, and 340-B buildings, the vault tanks, the 307 basins, and the RPS/RLWS piping networks.

The 340 Building was originally constructed in the early 1950's and houses the sampling hood, decontamination area, equipment room, control room; closely coupled to a below grade concrete vault. The vault houses two - 57 kiloliter (15,000 gallon) stainless steel tanks, and has removable concrete cover blocks. In the early 1960's an addition was added to the 340 Building which included a garage and load-out facility (WHC 1992b). The total area of the original 340 , the annex, and vault, is 4530 s.f. ${ }^{2}$.

The 340-A Building (1350 s.f. $)^{2}$ sits partially below grade and houses six 30 kiloliter $(8,000 \mathrm{gal}$.) stainless steel tanks within a concrete berm. The tanks are currentily available as backup storage for the vault tanks.

The 340-B Building (3200 s.f. $)^{2}$ is termed the rail load-out facility. The building was initially constructed to accommodate two 76 kiloliter $(20,000$ gal.) rail tank cars. Currently, only the east side can receive rail cars. The tracks on the west side have been removed and this area is only used for storage. The two sides are now divided by a concrete shielding wall; which projects along the south end of the east side, extending protection to the 340 control room.

The RLWS is composed of encased stainless steel piping connecting the 340 vault tanks to the waste generators. It is used to collect 1 iquid mixed wastes. Facilities connected to the RLWS system are the $324,325,326,327$, and 329 buildings. Other generator facilities transfer containerized wastes via these connected facilities or directly to the 340 Complex. The waste generators are responsible for ensuring that strict waste acceptance requirements are met.

The liquid mixed waste is collected at the 340 Complex and periodically transferred to a rail tank car in 340-B East, for transport to double she11 tanks (via the 204-AR Waste UnToading Facility) in the 200 Area.

The 340 Building is provided with a ventilation system servicing all of the rooms except the control and mechanical equipment rooms. Air flows from uncontaminated areas toward areas with a potential for contamination. The potentially contaminated areas are filtered through a single stage of $99 \%$

\footnotetext{
2 These square footage numbers were obtained from "Past Practices Technical Characterization Study -300 Area -- Hanford site", WHC-MR-0388, (WHC 1992b).
} 
HNF-SD-LEF-SSP-001, Rev. 1

filters. Exhaust from this area combines with exhaust from the change-room, truck lock, and operator office and is filtered through two stages of HEPA filters prior to discharge to the environment.

The 340 Vault and tanks are serviced by a common ventilation system. Supply air is electrically heated in the winter to provide freeze protection. The exhaust discharges through a stage of dust stop filters, two-stage HEPA filters, and two exhaust fans located just east of the vault. A charcoal absorber stage is also in line, but is only maintained when a potential source exists for iodine-131 releases. During normal use the fans are alternated with one in standby. A control damper on the vault line is used to maintain a higher vacuum in the tanks than in the vault. The off-gas line from the tanks contains a demister ahead of the tie-in to the filter system.

The RPS system serves as a collection system for non-hazardous process wastewater which is potentially radioactively contaminated. The RPS system includes underground piping, the 307 Basins, and four diverter stations. The 307 Basins were constructed during the same time frame as the RLWS and 340 Complex. The RPS diverters are capable of routing the wastes to either the RPS or the RLWS, and are located in the basements of the 324, 325, 326, and 327 laboratories. The 326 diverter station monitors the combined flow from the 326 and 329 Buildings. These diverters were upgraded in 1996 with more sensitive beta/gamma monitors (WHC 1995a).

The 307 Basins currently consist of four 190 kiloliter (50,000 gallon each) basins with associated valves, pumps, and pump controls. However, only half is useful capacity due to the location of the inlet pipes. Project W-345 (WHC 1993) re-lined the basins and provided the system with a batch-release capability. Wastewater determined to be unacceptable for the 300 Area TEDF (WHC 1994c) can be transferred to the 340 Facility vault storage tanks.

\subsection{Organization and Control}

The 340 Complex is now managed by the Rust Federal Services Hanford, under integration contractor Fluor Daniel Hanford, for DOE. Facilities generating waste received at 340 are operated primarily by B\&W or PNNL. The RLWS Disposal Approval Request system has been established to support this process. (PNNL 1989, WHC 1994d, RFSH 1996c).

The 340 Complex (and the 300 Area TEDF) are managed under the vice president of the Waste Management Operations organization within RFSH. Daily operations/maintenance for both facilities falls under the oversight of the 300 Area Liquid Effluent Facilities (LEF) manager, while immediate control for the 340 Facility is provided by the Facility Operations unit. LEF groups providing support to both facilities include the 300 Area LEF Maintenance/Work Control and Process Engineering units.

WHC-IP-1000, 300 Area Liquid Effluent Facilities Administration (WHC 1994c), outlines policy for conduct of operations, general administration, engineering and work control. Training requirements are delineated in the Training Implementation Matrix: 340 Waste Handling Facility, (WHC 1995b). 
HNF-SD-LEF-SSP-001, Rev. 1

The 340 Facility normally has an operations manager, an engineer, 2 operators, and 2 Radiological Control Technicians (RCT) assigned to complete routines, monitoring and other assigned tasks. Additional operators are assigned to the facility as necessary. Similar resource allocation is made for work control and engineering support, and any additional support is assigned as required. The facility's cognizant engineer is responsible for identifying documents, drawings, instructions, or procedures that are affected by a facility change.

The Facility Evaluation Board conducts appraisals of PHMC facilities to verify compliance with DOE Order 5482.1B, Environment, Safety and Health Appraisal Program. Examples of activities covered by this organization include readiness reviews, design reviews, audits and appraisals, facility inspections, and operational surveillance and self assessments. The facility and operations are routinely, internally assessed to verify compliance with the intent of meeting applicable codes, standards, and regulations. These assessments are either conducted by qualified in-house personnel or are requested from support organizations. Findings are prioritized and corrective actions tracked.

The 340 Complex, via the RLWS, typically collects from 11 to 38 kiloliters (3,000 to 10,000 gal.) every 90 days. Additional volume could be generated as a result of diversions from the RPS. Sampling of this waste is periodic and is consistently performed concurrent with rail car shipments. Data on individual RLWS transfers is maintained by both PNNL and 300 Area LEF. This data always includes volume, chloride, gross radionuclide, and $\mathrm{pH}$ information.

\subsection{Environmental Compliance}

The 340 Facility is managed as a less-than-90-day waste accumulation area. Waste shipments, given the available capacities for storage and rail tankage capacities, along with the typical RLWS waste accumulation rates, could more effectively be made on a volume rather than on the time basis. Negotiations are underway with the regulators to attempt some relief for this encumbrance (see 3.1 ).

A management strategy was developed as part of negotiations for a Tri-Party Agreement (Ecology, EPA, and DOE 1989) milestone (M-32-09). It commits 340 Operations to perform specific activities which afford protection to the environment without either physical upgrades to the secondary containment ${ }^{3}$, nor the administrative actions such as daily visual inspections in radiation areas.

Built in 1953, many design features now required or encouraged under RCRA were employed within the 340 tank system. These features include the use of stainless steel tanks/piping, tanks with top penetrations, mostly welded joints, seamless jet pumps, additional containment structures, and use of

\footnotetext{
Note that a project $W-302$ was intended to provide for this, and had been designed to bring the main 340 waste storage system into compl iance with RCRA requirements. W-302 was validated in the spring of 1995 as a 1997 Line Item; however, because of budget Limitations, no capital funds were authorized. A value engineering (VE) study was conducted to look at options, which in turn advocated two follow-up studies. The resulting recommendations of PNNL/WHC (and subsequently supported by RL) provided both the impetus and foundation for the initial version of this deactivation plan.
} 
HNF-SD-LEF-SSP-001, Rev. 1

liquid level and leak detection instrumentation. A tank integrity evaluation was recently conducted on the 340 tank system. The results were approved by an independent professional engineer (WHC 1996b).

ERDA 1538 evaluated and "allows" (from a National Environmental Policy Act standpoint) current operation of liquid effluent streams in the 300 Area (ERDA 1975). Any alteration of routing or transportation of these liquid waste streams within the 300 Area and transporting up to the 200 Area plateau would require a new NEPA evaluation.

\subsection{Safety}

The current RPS \& 340 Facility safety bases address unacceptable risks appropriate to their respective foci, including fire, explosions, criticality, natural occurrences, industrial accidents, and exposure to radiation/toxins, noise, and electric shock. The 340 interim safety basis (ISB; RFSH 1996a) quantifies the operating safety envelope for the latter, establishing safety requirements that assure compliance within a Hazard Category 3 classification. The RPS/307 basin system is non-nuclear (Berneski 1995). Due to the limited remaining active life of the 340 Facility, its recently updated ISB will continue to serve in place of a Safety Analysis Report.

The 340 Facility is presently classified as an Isolated Facility per WHC-CM-429, the Nuclear Criticality Safety Manual (WHC 1994a, WHC 1996a). This category identifies facilities that contain or could contain more than $3 \%$ of a minimum critical mass of fissionable material, but no more than $1 / 3$ of an MCM.

As low as reasonably achievable (ALARA) practices are followed, and job safety analyses are performed to ensure minimal employee exposure to hazards. An unreviewed safety question (USQ) process is administered to ensure that any new practices or configuration changes to the facility do not exceed or effect the safety envelope/basis.

No excavation work requiring worker proximity to radionuclide contamination is expected during the early decommissioning phases at 340 . However, added worker exposure is probable during the removal of residual waste inventories from the various storage tanks. All controls warranted to afford protection from potential radionuclide releases will be implemented. Shielding of the tanks and tank cars reduce worker exposure to ALARA levels.

The fire detection and protection systems have been recently evaluated by a Fire Hazards Analys is (Roberts, 1995). Fire protection meets the "Improved Risk" criteria defined in and required by DOE Orders 6430.1A and 5480.7A and RLID 5480.7 (DOE 1989, DOE 1993), as well as the WHC fire protection manual (WHC, 1992a), and any applicable National Fire Protection Association codes. The fire alarm system is connected to the 300 Area fire alarm system. Fire extinguishers are installed in and around the facility.

Fire sprinklers will be installed in 340-B, primarily to permit relaxation of storage capacity restrictions, thereby allowing for greater beneficial use of this facility. After termination of routine liquid mixed waste activities at $340,340-B$ west can continue to store solid waste generated from on-going 


\section{HNF-SD-LEF-SSP-001, Rev. 1}

RPS/307 operations, as well as terminal clean-out activities within the balance of the 340 complex.

Existing work procedures will continue to be implemented to ensure the safety of operating, maintenance, and any construction personnel in the area. Safety features (such as shower/eye wash stations, exit lighting, intercom phones) will be maintained until no longer substantially beneficial.

The 340 site is not subject to through traffic. Existing roads will be maintained based on expected service and use. The existing fence will continue to provide adequate access control. 
HNF-SD-LEF-SSP-001, Rev. 1

\subsection{DEACTIVATION STRATEGY}

This section constitutes the core of the plan. As noted in section 1.2 (assumption ' $a$ '), the deactivation timetable is somewhat fluid at this time. Associated modifications to strategy are discussed in section 3.1.

\subsection{Near Term Actions}

"Near term" is defined here as the time period from the present until an appropriate cutoff date for routine liquid mixed waste receipts is selected. The immediate deliverable associated with documenting whatever timetable is developed and approved, depends upon the duration of any extension to 340's mission: a) If the September 1998 date is extended more than a year or two, this plan will be revised and issued near the end of FY97; on the other hand, b) If 340 's deactivation is imminent, rather than revise this plan, a Project Management Plan (PMP) will be immediately initiated instead. The primary activity during this period will be RFSH working with B\&W and PNNL, through FDH and RL, to reach a consensus on a new date; however, this period of time may also be used to begin tentative work on long-lead tasks outlined in later sections.

\subsubsection{Facility Mission}

Indications from Babcock \& Wilcox Hanford (B\&W) are that the deactivation of the 324 and 327 laboratories might require an active 340 Facility beyond the September 1998 end date now established. This need, along with funding shortfalls for some of the upgrades required to meet September 1998 (i.e., providing capabilities both for waste storage and load-out at the 325 laboratory, and for accepting specific trucks at the 204-AR waste receiving facility), combine to challenge the realization of that goal from both suitability and feasibility standpoints.

It is recommended that RFSH work with all interested parties to determine a realistic shutdown timetable, and document this decision. Cost estimates for three different operating/deactivation scenarios are now being developed in support of a Planned PHMC presentation to RL in January 1997. The scenarios include the September 1998 "baseline", a short term extension (primarily to support 324/327, assuming RLWS receipts at least through 2001), and a long term extension (continued 325 support, 20 yearst) as a bounding case.

B\&W expects PNNL to complete their activities at 324/327 within two years, but they have yet to establish a firm clean-up timetable. Current B\&W plans call for draft PMP's for 324 and 327 decontamination work by the end of July 1997. On this basis, RFSH intends to complete the 340 timetable evaluation by the end of August 1997. A detailed work breakdown structure for 340 deactivation, including budgets and schedules, will be developed as part of a separate PMP.

\subsubsection{Impacts of extended 340 Operations}

The 340 Facility may be called upon to receive liquid wastes several years beyond the September 1998 date (section 3.1.1). This section briefly examines some of the ramifications of that possibility. 
HNF-SD-LEF-SSP-001, Rev. 1

The recent tank integrity assessment (WHC 1996b) concluded that the next tank assessment need not be completed before the end of 2005 . However, this does not rule out having to line the secondary containment vault, as may be required pending negotiations with regulators. Preliminary vendor discussions suggest that a reliable membrane could be applied to the vault floor and walls with minor preparatory work.

Another potential upgrade involves replacement of the vault/AGS ventilation off-gas filter system. Improved operational reliability ${ }^{4}$ could also be attained by replacing valve actuators and position indicators, the oil seals on the agitators, and the primary tank sampling system. The cost for such improvements have yet to be estimated. The tank pumps have been replaced within the last 20 years, and the current sample pump could be used as backup.

There are other lower priority type upgrades that have been dropped from consideration due to the pending shutdown. of those that need to be reviewed under an extended life scenario, some activities with potentially significant budget/schedule implications are the conversion of the 340 ISB to a BIO or $S A R$, and/or obtaining a RCRA permit. If the assumption regarding railroad availability (section 1.2 , b) doesn't hold, then provisions for converting to truck shipments could be required.

The above actions should serve to extend the $340 \mathrm{Facility}$ life into the 2001 to 2005 time-frame (subject to examination in more detail following agreements on the timetable). Any long term mission (such as the bounding scenario mentioned in 3.1 .1 ) would probably require a major upgrade -- very likely the replacement of much of the 340 Facility (on the order of Project $W-302$, WHC 1995c).

\subsection{Interim Operations}

"Interim" is defined as the time period from the issuance of the final version of this plan (representing sanctioned consensus) until the routine mixed liquid waste receipts are discontinued. While this period of time may also be used to begin work on many of the tasks outlined in later sections, Section 3.2 only addresses changes of an operational nature.

\subsubsection{SSC Related}

There are several systems, structures, and components (SSC) essentiai to 340 operations. The SSC associated with those portions of the 340 Complex to be deactivated, must be maintained to ensure the facility is able to support the laboratories until the new load-out station is constructed. Systems with redundant capability or atypical access constraints could continue to be operated while being formally placed in a "run-to-fail mode", allowing focus on essential areas and reducing the overall maintenance cost for the facility.

\footnotetext{
4

The 90-day storage/shipment clock places a premium on system reliability. If the EPA Project XL proposal is approved, and 340 is able to schedule shipments based on volume versus calender limitations, then such added operating flexibility could better accomodate a repair-as-needed mode of operation.
} 
HNF-SD-LEF-SSP-001, ReV. 1

The 340 facility currently has over 100 different preventive maintenance (PM) procedures. Many of these are on an annual or more frequent recall basis. Presented below are the systems considered essential and requiring preventive maintenance. PM on all other systems will be systematically evaluated for reduction or deletion. After PNNL provides replacement waste storage capabilities, the essential list will again be reassessed.

\section{Alarm System and Emergency Lighting}

The majority of the maintenance work for these systems consists of functional checks and PM, and as a safety issue will be continued.

\section{RLWS}

The following are the major, critical components of the radioactive liquid waste system.

tanks TK-1, TK-2

at least three of the six AGS tanks

RLWS valves RL-: $1-5,15-25$

pumps TP-1, TP-2, TP-5

agitators $A G-1, A G-2$

o il pump 0P-1

valve box leak detectors

tank level instrumentation

PMs associated with the RLWS equipment include pump/valve interlock checks, level measurement instrumentation calibration, and leak detector functional checks. Maintenance will continue on these components/systems.

Heating Ventilation and Air Conditioning (HVAC)

The K- 1 HVAC system services 340 's waste tanks. As long as there is a source term, this HVAC system will need to be operational. The K-3 system services the 340 Building. Occasionally, generators deliver waste in containers for disposal into the waste tanks. This is completed in the 340 Decontamination Area. This area is also used to decontaminate and maintain equipment used in the facility. Also, the sampling hood is where samples of vault tank waste are collected using the TP-3 pump. The K-3 system is required to operate so long as these activities take place. PMs on these $K-1$ and $K-3$ systems cover differential pressure gauges, fans, stack flow rates, and sampling

instrumentation. Electric heaters provide freeze protection.

\section{Radiological Monitoring}

The number of instruments and their calibration/maintenance frequency is prescribed by Rad Con procedures. Changes may result from either changes within the facility or to the Rad Con requirements.

The vacuum system is used in obtaining stack samples. Even though it uses a lead/backup setup, which should allow time to respond to a failure of one side, the regulatory significance warrants continued preventive maintenance as long as the K1 \& K3 HVAC systems remain in service. 
HNF-SD-LEF-SSP-001, Rev. 1

\section{Fire Protection}

Fire Protection is essential.

PMs will continue to be performed during this near term period. (WHC 1992a) A project is underway to install a sprinkler system in $340-B$.

\section{Balance of Plant}

This includes equipment such as pump TP-3 and its associated valves, and the K-2 (340-B east) ventilation, compressed air and process water systems. As long as the services afforded by 340 are needed, all operational PMs will be performed, and even minor upgrades effected. However, once agreement on a final waste receipt date is reached, an appropriate "run-to-fail" mode of operation will be implemented for this type of equipment. With the exception of the $K 1$ and $K 3$ ventilation systems, 340 systems are run as batch operations. Wastes are received with prior notification, and subsequent transfers out are scheduled on a less-than-90 day time period. While loss of the "run-to-fail" systems can impact waste transfers, through proper control of transfers, the facility should have time to respond. Some balance-of-plant items suggested for this category:

- TP-3 in the valve pit. The facility has operated without the TP-3 pump in the past. The maintenance on this system is expensive. It is located in a high dose rate, high contamination area. [TP-3 could be useful during tank clean-out, as its inlet is lower than the main transfer pumps TP1/2]

- The compressed air system operates many of the RLWS valves within the 340 Facility and the level detection system. The system is equipped with a lead and backup compressor. This backup capacity should afford facility personnel adequate time to detect and replace a single compressor failure.

- The process water system is used to provide seal water to the RLWS pumps, flush lines and decontaminate the facility. Again these are batch operations that the facility can control. The process water system is fairly new and not located inside any radiologically controlled areas. Repairing equipment outside radiological areas in not normally a problem.

of course, there is some risk to the "operate to fail" mode. The facility has experienced waste receipt without prior notification. Any waste in large quantities, such as a RPS divert, could require the facility to transfer waste to backup storage with little notification. Pressure from the 90-day clock also places a premium on equipment reliability. Another trade-off is that while preventive maintenance cost may be reduced, repair costs could increase.

\subsubsection{Management Related}

Configuration management will be performed in accordance with the SSC's anticipated disposition category. Essential SSC remaining in operation will have their drawings, vendor information, and design bases maintained during this period. Documents required to support the design or use of those SSCs which are removed or disposed of, will be voided. Any usable surplus SSCs or SSCs transitioned for later disposition will include existing documentation in 
the turnover package. Documentation will be stored for any remaining SSCs whose disposition has not yet been determined.

The management of records will follow applicable sections in WHC-CM-3-5, Document Control and Record Management Manual (or its relevant PHMC successor) to ensure the availability of records needed to support the transition, surveillance and maintenance, and/or disposition phases of 340 decommissioning. A controlled notebook recording activities as work is performed should be maintained as a facility shutdown logbook (WHC 1990).

Self assessments will be performed in several areas to demonstrate continued policy compliance and to alert management to any deteriorating conditions.

The initial proposed changes will entail NEPA coverage, as will the eventual D\&D of 340. PNNL has drafted a Categorical Exclusion (CX) as directed by RL (PNNL 1996d), which covers many of the changes related to the transfer of storage and transport duties from 340 to a PNNL facility. As currently written, the scope of this $C X$ does not include all of the activities proposed later in this chapter, and it may be determined that an Environmental Assessment would more readily afford overall NEPA coverage.

\subsection{Facility Stabilization Actions}

The preferred approach to stabilization is removal of the hazardous and/or radioactive inventory. Wherever this is not possible, then the isolation and containment of contamination, followed by proper posting and documentation, will suffice until final disposition. The first sub-section identifies known areas of concern, followed by proposals for reducing the inventory and/or associated hazard as much as practicable.

\subsubsection{Inventory Description}

There are several areas within the RLWS that have inventories to be addressed. These include the 340-A tanks, 340-B East, vault tanks, the 340

Decontamination Area and the associated piping. The discussion of the inventory will include information on removable contamination. To give these values meaning, a point of reference may be helpful. In accordance with Health Physics procedures, an article with greater than $1,000 \mathrm{dpm}$ beta/100 sq $\mathrm{cm}$ and/or $20 \mathrm{dpm}$ alpha/100 sq $\mathrm{cm}$ removable contamination must be managed as radioactive. All contamination data presented are given in $100 \mathrm{sq} \mathrm{cm}$ smears.

\section{0-A Tanks Radioactive Inventory}

The 340-A tanks are used as backup storage to the vault tanks. Unlike the vault tanks, the 340-A tanks are not equipped with agitation. When waste is transferred to these tanks, most solids settle to the bottom of the tank. These solids are not resuspended by the draining process, allowing for a build up. This has led to an increase in the dose rate surrounding the area and a need to address the potential for fissile material accumulations. In 1982, the facility evaluated the build up problem. Operations obtained samples of the solids and determined the volume of solids accumulated. The sampling effort was followed by a successful effort to flush the solids back to the 340 vault tanks. A similar sampling effort took place in 1995. Results indicate 
HNF-SD-LEF-SSP-001, Rev. 1

that the tanks conservatively contain approximately 1.5 inches of solids and have accumulated approximately 34 grams of fissile material. The sample results also show the presence of $\mathrm{Cs}-137$ and $\mathrm{Eu}-154$. These hard gamma producers contribute to the increase in dose rate for the surrounding area.

In addition to the solids accumulation in the tanks, the valves in 340-A have had a problem with contamination. In 1995, removable contamination as high as $100,000 \mathrm{dpm}$ beta and 7,000 dpm alpha was measured.

\section{0-B East Radioactive Inventory}

The 340-B East facility is used for loading RLWS into railcars for shipment to the 200 East Area. The facility is a surface contamination area. Data from 1995 showed contamination spots on the floor as high as $700,000 \mathrm{dpm}$ beta and $4000 \mathrm{dpm}$ alpha, and following a decontamination effort to $8000 \mathrm{dpm}$ beta and no detectable alpha. Every few years the facility undergoes a major decontamination effort to reduce levels, but these upper values represent a conservative planning basis. The majority of the valving is located on a platform $12 \mathrm{ft}$ above the floor. The platform floor is made of steel grating.

The 340 Decontamination Area Radioactive Inventory

The hood located in the 340 Building decontamination area has been used for obtaining samples from the Vault tanks. Contamination levels as high as $500,000 \mathrm{dpm}$ beta and $1000 \mathrm{dpm}$ alpha have been observed. The hood drains into the 340 'decon' sump. This sump is used for transferring containerized RLW into the vault tanks. The sump is routinely flushed after transfers and safety shower tests. Surveys from 1995 indicate contamination in the sump at levels near $20,000 \mathrm{dpm}$ beta and $450 \mathrm{dpm}$ alpha. The floor area has remained stable with contamination levels near $1000 \mathrm{dpm}$ beta and less than $20 \mathrm{dpm}$ alpha. The samples lines from the hood are more contaminated. Dose rates from the 1 ines range from $180 \mathrm{mrem} / \mathrm{hr}$ to $120 \mathrm{mrem} / \mathrm{hr}$.

The 340 Vault Tanks Radioactive Inventory

The vault tank inventory with respect to solid accumulation is less certain than the 340-A tanks. Because the tanks are agitated, there is less of a concern than the 340-A tanks with solids buildup. The radioactive concentration of the waste has declined in recent years. Tank samples from 1989-1993 averaged four times higher in beta and 3 times higher in alpha than the more recent period between 1994-1996. Dose rates around the tanks have also declined. In November 1990 , dose rates under the tank exceeded 5000 $\mathrm{mrem} / \mathrm{hr}$ and the vault sump area dose rate was $2000 \mathrm{mrem} / \mathrm{hr}$. In 1995, the highest dose rate under the tank was $1500 \mathrm{mrem} / \mathrm{hr}$ and the sump area was 500 mrem/hr. Recent sampling/inspection attempts were able to show there hasn't been any significant solids accumulation, yet were inconclusive with respect to completely ruling out the possibility. Therefore, a potential one inch sludge layer in each tank has been postulated as the current basel ine for conservative fissile inventory tracking purposes (RFSH 1996b).

\section{Piping/Valve Boxes}

There are 15 valve boxes associated with the RLWS. Dose rates in the valve boxes vary. A survey in 1995 showed dose rate from less than detectable to 80 
HNF-SD-LEF-SSP-001, Rev. 1

$\mathrm{mrem} / \mathrm{hr}$. There is also removable contamination in some valve boxes. Most valve boxes indicate less than detectable. Valve box 8 had levels up to $55,000 \mathrm{dpm}$ beta.

\section{Hazardous Material Inventory}

The issue of hazardous constituents must be addressed in addition to the radioactive inventory. There is a potential to accumulate heavy metals in the bottom of tanks and in the gravity feed lines. Removal of the solids/ precipitants has been successfully accomplished in the 340-A tanks in the past. Experience from the $L-070$ project revealed solids can be flushed from lines. Therefore only the vault/tanks within the RLWS may remain as areas of significant concern with regard to contaminated sediment/scale removal.

The facility clean-up must also address the issue of 1 isted waste. Some streams entering the RLWS have been designated as F listed wastes. This type of hazardous designation is independent of quantity or concentration, and is more difficult to address than characteristic wastes. All RLWS components must be considered 1 isted waste due to the nature of past PNNL disposals (PNNL 1996c). After decon/cleanup the tanks, piping and other components could be evaluated for other beneficial uses under provisions of WAC 173-303 (Ecology 1995).

\subsubsection{Inventory Reduction Actions}

Preliminary evaluations of inventory reduction tasks have identified actions that will help minimize long term S\&M activities. Details of these actions are being developed and will be refined as additional information becomes available. Other options that may arise will be evaluated against these actions.

It is appropriate to flush out as much of the facility inventory as possible while the capability to remove the waste is readily available. The 340-A tanks are primary candidates for flushing and the logical place to start. Much of the residual contamination was successfully removed in 1989 . Removing this material will reduce the dose rate to the surrounding area and could eliminate the need for active ventilation during the long term maintenance and surveillance phase. (WHC 1994b) Since Rev. 0 issuance, negotiations related to obtaining a Notice of Construction (NOC) to permit initial tank clean-out is presently centered around the possible need for upgrading the Kl filters.

The sink/hood in the 340 Building decontamination area has had problems with contamination creeping out of the line and sink trap. To eliminate this, the hood should be decontaminated, flushed and the piping removed/capped where it enters the room. The removed equipment could be disposed of as radioactive waste. While this would eliminate the capability to sample the vault tanks using TP-3, the facility has an alternate sampling system that does not rely on $\mathrm{TP}-3$.

Once the hood/sink and the decontamination area have been cleaned up and waste no longer discharged to the RLWS from the sump, there may be justification to eliminate active ventilation of the 340 building. Again, this would reduce long term maintenance and surveillance. 
The last sections in the 340 facility for clean-out would be the vault tanks and the load-out facility. As noted in 3.3.1, a recent remote visual inspection and sampling attempt were unable to definitively determine whether there is sludge buildup inside the tanks. Should subsequent inspections show significant quantities of sludge, further sampling efforts or other external determinations will be used to ascertain the extent of any fissile material that may be present. Based on the information, a determination can be made whether an acid flush is possible to remove the sludge and whether or not the tanks would continue to require active ventilation.

The equipment in 340-B east should be flushed to remove all residual waste. once complete, in order to further cut down on exposure levels and the risk of contamination spread in 340-B, the RLWS valves and piping should be removed and disposed of as low level waste. The platform should also be wiped down or decontaminated in the best manner possible, generating minimal liquid waste.

Facility status after these inventory reduction actions are completed, is anticipated as: 340-A (tanks \& building) -- cleaned to no longer require radiation buffer zones, and drastically reduce S\&M needs (these tanks would still serve an emergency back-up); 340 'Decon' area and hood -- cleaned and/or removed such that ventilation and current levels of S\&M are no longer needed; 340-B east - cleaned to the point that ventilation and current S\&M are not required; and finally the 340 vault and tanks -- cleaned to where little S\&M is needed, and possibly the deactivation of the Kl HVAC system.

\subsection{De-coupling RPS from RLWS}

This section discusses impacts on the RPS once 340 tanks are unavailable, and proposes conceptual modifications to accommodate those needs. While most of the associated tasks fall within the interim period defined in Section 3.2 , they are segregated here due to a distinction from strict deactivation.

The RPS provides process wastewater with an alternate route for disposal should significant radioactivity be detected. This route is through the 340 RLWS tanks, a path that will be eliminated once the RLWS has been shut down.

As briefly outlined in 2.1, there are now two locations in the RPS system that allow waste to be routed away from the process sewer. The first is at the generator building, where if radioactivity is detected in its RPS flow, it is diverted to the RLWS tanks. The remaining RPS waste flows from the other buildings are not affected. This feature minimizes the volume of waste to be managed as RLW. The second location for waste diversion is the 307 basins. These basins are subject to batch sampling. If radioactivity is detected, the contents of the basin may be pumped directly into the RLWS tanks.

The combined building flowrate into the 307 basins can reach 50 gallons per minute. Each basin can effectively hold 25,000 gallons, thereby taking as little as 8 hours to fill. It then takes 2.5 hours to dry and count a sample. The discharge pumps, at $\sim 180 \mathrm{gpm}$, take $\sim 2.3$ hours to empty a basin. By this time, the second basin could be $60 \%$ full. It is obvious that fairly quick response actions must be taken in the event elevated radioactive levels are detected, or there may be multiple off-specification basins requiring special 
handling. This constraint is made more restrictive under the changes proposed in Section 3.4.1.

The former PNNL 324 and 327 facilities are nearing the completion of their operating missions, and last November were turned over to the Site transition contractor (B\&W) for eventual deactivation. Miscellaneous streams from cooling systems and the potential for a fire system activation requires continued RPS availability. These facilities may be de-coupled once cleaned to the point where they pose an acceptable risk. The 329 and 326 facilities, while no longer dedicated RLWS users, are nonetheless expected to remain connected to the RPS diverter system for the foreseeable future. Therefore the $324,325,327,326$ and 329 buildings would be initially included within the "new", post-RLWS-shutdown, RPS/307 system. Obviously, any significant delay in that shutdown might alter this strategy for some of these generators.

\subsubsection{Changes to Diverters and Associated Operational Controls}

The future operation of the basins will require even closer cooperation between the 307 Basin operators and the RPS generator personnel. A study directed by Rev 0 of this plan (RFSH 1996d) has evaluated options for implementing this task, including: a) the use of alarms from building-specific monitoring stations to use existing valving to direct the entire RPS flow at 307 to a dedicated 307 basin; and b) leaving things essentially as is, except jumpering the RLWS piping from near the current vault tank inlet over to a dedicated 307 basin.

Recomendation: The baseline operation for the 307 basins will be to hold one basin in reserve for upsets detected at generating facilities. A cleaned RLWS piping network will be re-directed to this basin, to carry building-specific diversions during off-normal episodes. A decision (outlined in more detail in Rev 0 , but summarized here) related to the resulting potential for the basins to now receive wastes that formerly would have gone to the underground vault tanks, is that this does not justify any form of basin cover or enclosure.

\subsubsection{Truck Load-out Station}

The planned deactivation of 340 vault tanks and $340-B$ east will require an alternate method for removal of contaminated water from the basins. It is possible RL will announce a plan to end railroad operation under a phased withdrawal (counter to the section 1.2 assumption b). A loss of rail service would impact future shipments from the 340/307 Complex. The detailed analysis referred to earlier (RFSH 1996d) looked at several load-out options, including: a new building; a simple, exposed gravel or paved area with a new valve station; and even (despite a desire to close as much as possible) the modification of $340-B$ east to accommodate trucks.

Recommendation: In light of the low frequency postulated for situations that might require liquid waste shipments, the preferred baseline recommendation is to provide truck access to a load-out station where a valved-tee manifold would be installed on an existing above ground line between the basins and the vault tanks. This approach also requires extensions for the existing pumps that would be used, in order to more completely empty the basin. The access plaza shall be flexible enough to accommodate all realistic, available tanker 
HNF-SD-LEF-SSP-001, Rev. 1

trailers on Site. Should the frequency estimate prove low, an enclosure can be added later.

\subsubsection{Stand-by Treatment}

The potential for experiencing off-specification basins not suitable for treatment at TEDF is placed at less than once every 20 years (RFSH 1996d). While provision for shipments is recommended, the ability to pre-treat some out-of-specification wastes to a point where TEDF could complete disposal could offer substantial cost savings. The aforementioned study considered either a permanent, flexible treatment system or an as-needed package system. It addressed aspects such as resin storage shelf-life, secondary waste disposal, and needed treatment rates.

Either of these options, coupled with the truck load-out, provide a means of removing contaminated 1 iquids from the 307 basins. The truck option alone does not provide an efficient capability to remove large quantities of water, and the treatment options should not be used to handle highly contaminated wastes due to exposure concerns. A combination of the shipment and the low capital cost treatment option provides the most cost effective means of disposal of contaminated basin water.

Recommendation: Design a portable system utilizing a pre-filtration module and an off-the-shelf demineralizer package. After use, the filter cartridges and resin columns would be disposed as low-level radioactive waste. The system is expected to cost around \$7,000 up front, and about \$2000 per use.

\subsection{Interim maintenance \&urveillance}

With the facility inventories stabilized, the facility will begin systematically deactivating non-essential systems. ER prefers that water supply, fire protection, HVAC, and electrical systems/services be reduced to the maximum extent possible (DOE 1995b). ER normaliy asks that emergency lighting systems be removed, electrical service controls be centralized, any loose asbestos be removed, and any equipment/systems that might be needed during later D\&D be mothballed according to manufacturers recommendations.

Without waste in the 340-A tanks there is no need for facility heating, leak detection/alarm capability and area radiation monitors. It is possibie that the tanks will not require active ventilation.

When 340-B east is deactivated there will be no need for leak detection/alarm capabilities, area radiation monitoring, and the $\mathrm{K}-2$ ventilation system. The ventilation filters would be removed and disposed of as waste. The heaters can be deactivated, the process water valved out and the lines drained. Any remaining sanitary water legs into the building must be isolated and removed. The continued need for active fire suppression, after combustible material are removed from the facility, requires further evaluation.

The future use of the 340 building must be determined before approaching deactivation of essential systems. The facility is equipped with process water and fire sprinkler protection. This may be used an indoor storage area 


\section{HNF-SD-LEF-SSP-001, Rev. 1}

for continuing basin activities. Decontaminating the 340 'decon' area and removing the sump, hood, and associated lines may be sufficient to justify completely deactivating the $\mathrm{K}-3$ ventilation system. The filters would be removed and disposed of as waste. Portions of the ventilation may remain active for heat/cooling if the facility is to remain in use. Sprinkler and process water systems should be drained before eliminating the heat portion of the ventilation.

It is difficult to predict whether the ventilation system will be required for the 340 vault tanks once the system is flushed. A clean-out goal could be to reduce the source term (through tank flushing, vault decontamination, and perhaps an in-kind filter change-out) sufficient to drop the 340-NT-EX stack from the WDOH register of major stacks. This would eliminate the need for continuous stack monitoring as well as the potential need for any further HEPA filter housing upgrades. Upgrades for remote monitoring may remain desirable to minimize facility inspections.

The facility is currently inspected daily, seven days a week. This inspection covers operations equipment as well as the essential systems defined earlier. As systems are phased out the inspection frequency may be reduced. The 1ong term goal is to reduce or eliminate facility inspection for the period leading up to final decontaminating \& decommissioning.

Other conditions that are expected (DOE 1995b) upon completion of deactivation include: removal of all unneeded supplies/spares/tools, closing all building penetrations, repairing any roof leaks, servicing monitoring systems, cleaning and releasing radiological zones, ensuring drawings are up-to-date, finalizing outstanding occurrence reports, and securing all entrances. The schedule in 4.0 lumps these activities under "Misc. Deactivation Tasks"; where details await scheduling in the PMP and other later documents.

5 As al ready discussed in 3.2.2, it may not be possible to effect the clean-out without first upgrading the filter system. 


\section{HNF-SD-LEF-SSP-001, Rev. 1}

\subsection{SUMMARY SCHEDULE}

This section provides a synopsis of the principle undertakings associated with this plan. The activities associated with the deactivation of the 340

Facility, as outlined in the five sub-sections of 3.0 , fall into the following basic areas:

Near term actions

- outline various operating scenarios and develop associated costs

- reach consensus on a responsive/feasible service date for 340

- obtain RL approval and document decision

Interim operation

- run-to-fail classification

- preventive maintenance on essential SSCs only

- Record Management updates

- prepare project management plan

Deactivation of 340, 'decon' area and vault, 340-A, and 340-B east

- blank RLWS lines

- terminal clean-out of wastes

- process equipment/material surplusing

Replacement for 340 (and possibly rail) services

- RPS re-routing and de-coupling

- provide 307 load-out and standby treatment capabilities

- [includes the 325 upgrade and 204-AR modifications not described in this document]

Preparations for S\&M phase

- negotiate end-point criteria

- evaluate and effect upgrades to facilities/support systems

These activities are relationally presented on the Figure 4-1 schedule. Also shown are some baseline operating and maintenance activities currently identified in Multi-Year Program Plan (MYPP) documents. Some of these baseline activities may be impacted by this plan (e.g., more frequent safety basis revisions, added waste samples, increased work package preparation and tracking, etc.). Not included on Figure 4-1 are the 204-AR and 325 laboratory modifications that, while potentially integral to the scope of this plan, fall outside the jurisdiction of the plan custodian.

As is obvious from the assumptions presented in 1.2, changes in budget, rail availability, lab missions, waste volumes, regulations, etc., could impact these projections. Also, certain tasks (such as preparations for the S\&M phase) must await the results of intervening work (in this example, acceptable end-point criteria, and facility condition post-TCO) before they can be scoped with any confidence. Therefore, as this effort proceeds, official budget planning instruments (Activity Data Sheets, Risk Data Sheets, and the MYPP) should be consulted for better break-out and more up-to-date information. Subsequently planned project specific and programmatic decommissioning documentation will also provide more detail. 


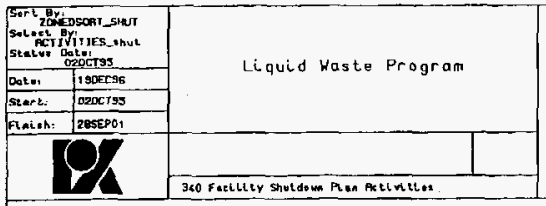

\section{Rust Federal Services Hanford}

340 Facility Shutdown Plan

FY 97 - 01

Drawn by stow Sanbom 376-5043

\begin{tabular}{|c|c|c|c|c|c|c|c|c|}
\hline \multirow[b]{2}{*}{ Acurity } & \multicolumn{8}{|c|}{$12 / 19 / 06$} \\
\hline & Description & start & Fmimath & FY 97 & FY 98 & FY 99 & FY 00 & FY 01 \\
\hline \multirow{2}{*}{$\begin{array}{l}\text { SLO PLANT } \\
1 \text { P2940810A }\end{array}$} & OPERATIONS & \multirow[b]{2}{*}{$10 / 0 z / 95$} & \multirow[b]{2}{*}{$00 / 28 / 01$} & & & 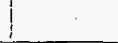 & & \\
\hline & S40 PLANT OPERATIONS & & & & & & & \\
\hline \multicolumn{2}{|c|}{ SeO MANTENANCE (SNECO) } & \multirow[b]{2}{*}{$10 / 02 / 80$} & \multirow[b]{2}{*}{$09 / 28 / 01$} & & & & & \\
\hline IAPS400ZOA & St0 MAITTERANCE (SURECO) & & & & & & & \\
\hline \multicolumn{2}{|c|}{ SAO FACIUTYY REC. COMPLIANCE } & \multirow[b]{2}{*}{$10 / 02 / 05$} & \multirow[b]{2}{*}{$08 / 20 / 01$} & & & & & \\
\hline 1N2380030A & 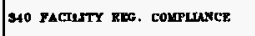 & & & 1 & & & & \\
\hline
\end{tabular}

FIMAL SHUTDOWW DATE

1ARA4X010B DETERYINE DATR FANAI STUTDOTI

PAEPARE PRONEGT MGIT. PLAN

1A234T010C PREPLRR PEOJECT YNAGTMENT PTAN

340 A IMENTOAY REOUCTON

LAESAYOAOD SAO A INVETTORY MEDUCTON

MODIFY APS SISTEW - 307 EMSINS

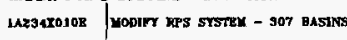

340 DECON AREA IWW REDUCTON

14ESAX010\% SHO A MRCON AHEA INY EEDUCTOM

390 VAULT TANK WN REDUCHON

JAzSSXO106 S40 VAULT TANG WVBNTOKY EKSOCTION

S4OB EAST WVENTOFY REDUCTION

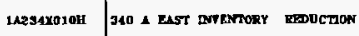

MISCELAMEOUS rasks

LAZ34X010J MLSCELWNEOUS TASTS

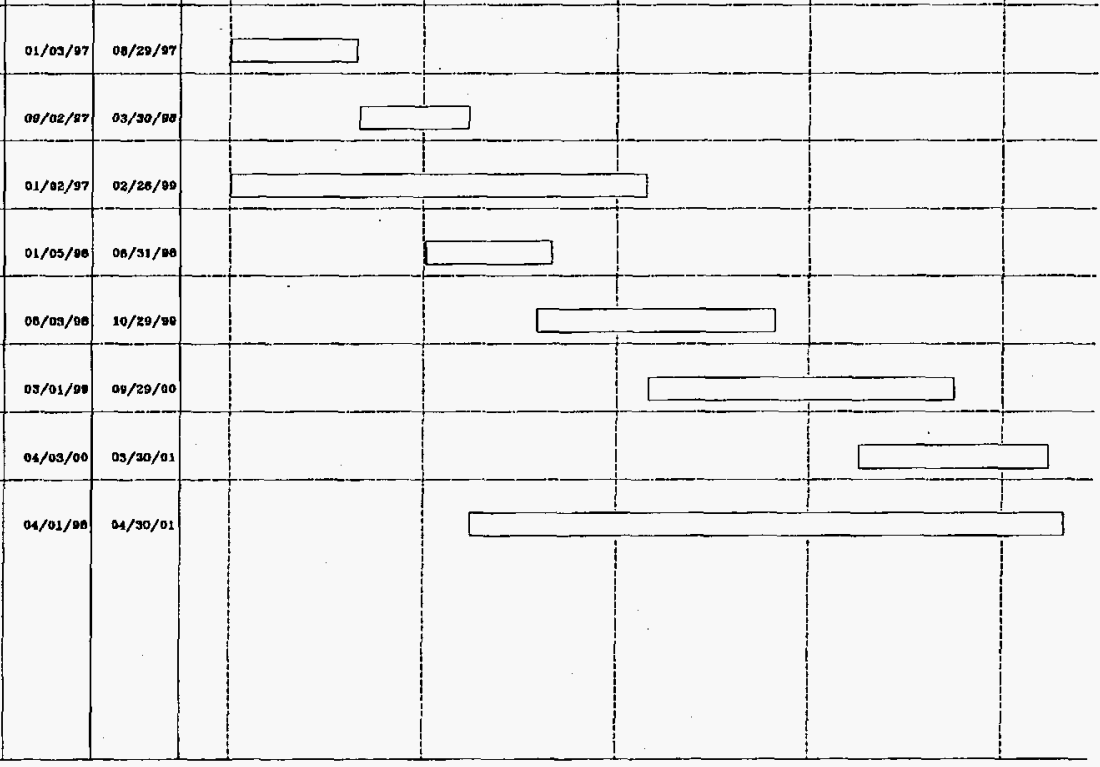


HNF-SD-LEF-SSP-001, Rev. 1

\subsection{REFERENCES}

Berneski, L.D. 1995, Hanford 300 Area Retention Process Sewer - Inventory at Risk Calculations and Safety Analysis, WHC-SD-WM-SAD-027, Rev. 0, Westinghouse Hanford Company, Richland, Washington.

DOE 1989, General Design Criteria, DOE Order 6430.1A, U.S. Department of Energy, Washington, D.C., April 6, 1989.

DOE 1993, Fire Protection, DOE Order 5480.7A, U.S. Department of Energy, Washington, D.C., February 17, 1993.

DOE 1995a, Facility Deactivation End Points Handbook, 3rd Draft - "for Use and for Comment", EM-60, Office of Nuclear Material and Facility Stabilization, U.S. Department of Energy, Washington, D.C., November 16, 1995.

DOE 1995b, Decommissioning Resource Manual, DOE-EM-0246, EM-40, Office of Environmental Restoration, U.S. Department of Energy, Washington, D.C., August, 1995.

Ecology 1995, Dangerous Waste Regulations, Chapter 173-303 of the Washington Administrative Code, State Department of Ecology, Olympia, Washington.

Ecology, EPA, and DOE 1989, Hanford Federal Facility Agreement and Consent Order, Washington State Department of Ecology, U.S. Environmental Protection Agency, and the U.S. Department of Energy, 01ympia, Washington.

Ecology, EPA, and DOE 1995, Tentative Agreement on Amendment Six to the TriParty Agreement, Section 8.0, "Facility Decommissioning Process", WA State Dept. of Ecology, U.S. Environmental Protection Agency, and the U.S. Dept. of Energy, Richland, Washington, November 1995.

EPA 1989, 40 CFR 60, Standards of Performance for New Stationary Sources, Title 40, Code of Federal Regulations, Part 60, as amended, U.S. Environmental Protection Agency, Washington, D.C.

EPA 1991, National Emission Standards for Hazardous Air Pollutants, Title 40, Code of Federal Regulations, Part 61, U.S. Environmental Protection Agency, Washington, D.C.

ERDA 1975, Final Environmental Statement, Waste Management Operations, Hanford Reservation, Richland Washington, ERDA 1538, Energy Research and Development Administration, Washington, D.C., December 1975.

PNNL 1989, RLWS Disposal Approval Requests, Pacific Northwest Laboratory, Richland, Washington.

PNNL 1996a, Letter (Incoming 9600138) "Integration of 325/340 Facility Recommendations with the $324 / 327$ Facility Transition Recommendations", M.J. Bagaglio to A.J. DiLiberto, January 16, 1996, Pacific Northwest National Laboratory. 
HNF-SD-LEF-SSP-001, ReV. 1

PNNL 1996b, Letter "Request for 325 Building Waste Operations Plan Due to the 340 Waste Handling Facility Shutdown", W.J. Apley to R.F. Christensen (RL), May 20, 1996, Pacific Northwest National Laboratory.

PNNL 1996c, Letter "Review and Comments of the 340 Waste Handling Facility Deactivation Plan", W.J. Apley to A.J. Diliberto, August 6, 1996, Pacific Northwest National Laboratory.

PNNL 1996d, Letter "Review and Comments of the 340 Waste Handling Facility Deactivation Plan", W.J. Apley to R.T. Stordeur, December 9, 1996, Pacific Northwest National Laboratory.

RL 1996, Letter (Incoming 9601262) "Proposal for Meeting Performance Based Fee Criteria Number 96-808: Prepare a 340 Waste Handling Facility Shutdown Plan", T.K. Teynor to President WHC, May 21, 1996, DOE-Richland Operations office.

Roberts, L.W. 1995, 340 Complex Fire Hazard Analysis, WHC-SD-WM-FHA-01l, Rev. 0 , prepared by Hughes Associates, Inc., Columbia, Maryland, for West inghouse Hanford Company, Richland, Washington.

RFSH 1996a, 340 Waste Handling Facility Interim Safety Basis, WHC-SD-WM-ISB003, Rev. 1, Rust Federal Services Hanford Company, Richland, WA, Oct. 4, 1996.

RFSH 1996b, Internal Memo 32330-96-019, "340 Waste Handling Facility Fissile Inventory: Response to the Facility Evaluation Board Issue 2.4.4.1", D.L. Halgren to L.W. Roberts, Rust Federal Services Hanford Company, Richland, WA, Nov. 26, 1996.

RFSH 1996c, Letter 9656156, L.W. Roberts to G.W. McNair (PNNL), M.S. Wright, and J.M. Seay (both B\&W), "RLWS Transfer Request Forms", Rust Federal Services Hanford Company, Richland, Washington, December 11, 1996.

RFSH 1996d, 307 Basins Engineering Study and Functional Requirements, draft HNF-SD-LEF-ES-002, Rev 0, Lo11, C. M., Rust Federal Services Hanford Company, Richland, Washington, December 1996.

WHC 1990, Management Requirements and Procedures, WHC-CM-1-3, MRP 6.15, "Facility Shutdown, Standby, and Transfer", Westinghouse Hanford Company, Richland, Washington, January 1990.

WHC 1992a, Fire Protection Program Manual, WHC-CM-4-41, Westinghouse Hanford Company, 1992.

WHC 1992b, Past Practices Technical Characterization Study - 300 Area Hanford Site, WHC-MR-0388, Westinghouse Hanford Company, December 1992.

WHC 1993, Functional Design Criteria, 307 Basin Maintenance Upgrades, Project 94-EWW-345, WHC-SD-W345-FDC-001, Rev. 0, Westinghouse Hanford Company, Richl and, Washington, May, 1993.

WHC 1994a, Nuclear Criticality Safety Manual, WHC-CM-4-29, Rev. 1, Westinghouse Hanford Company, Richland, Washington, May 23, 1994. 
HNF-SD-LEF-SSP-001, Rev. 1

WHC 1994b, Internal Memo 86700-94-057, "Use of Water for Shielding in 340A Above Ground Storage Tanks," D. W. Lindsey to D. J. Carre11, May 27, 1994.

WHC 1994c, 300 Area Liquid Effluent Facilities Administration, WHC-IP-1000, Westinghouse Hanford Company, Richland, Washington, September 16, 1994.

WHC 1995a, Conceptual Design Report: 300 Area Diverter Station Upgrade; Project W-353, prepared for WHC by ICF Kaiser Hanford Co., January 1995.

WHC 1995b, Training Implementation Matrix Per DOE Order 5480.20A: 340 Waste Handling Facility, Rev. la, R.B. Barmettler, Westinghouse Hanford Co., January 1995.

WHC 1995c, Engineering Study: 340 Facility Upgrade; Supporting Project W-302 Facility Secondary Containment and Leak Detection, WHC-SD-LEF-ES-001, Westinghouse Hanford Company, Richland, Washington, Nov. 3, 1995.

WHC 1996a, Criticality Safety Evaluation Report for 340 Facility, WHC-SD-SQACSA-20379, Rev. 1, Westinghouse Hanford Company, Richland, Washington, February 15, 1996.

WHC 1996b, 340 Facility Waste Tank System Integrity Assessment Report, WHC-SDWM-ER-546, Rev 0, E.J. Walter, WHC, Richland, Washington, May 15, 1996.

WHC 1996c, Facility Effluent Monitoring P7an for the 340 Waste Handling Facility, WHC-EP-0469-2, Westinghouse Hanford Company, Richland, Washington, April 1996 
HNF-SD-LEF-SSP-001, Rev. 1

\section{Appendix A Overview of deactivation process}

The objective of deactivation is to reduce physical risks and hazards; placing the facility in a passive/safe state such that the costs of both near and long-term surveillance and monitoring (S\&M) are minimized. This should be done economically, and consistent with the Site-wide mission goals, using existing technology and common sense engineering approaches. These actions should minimize the generation of additional waste/emissions and limit worker exposure. Defense-in-depth practices should be employed to provide as many layers of protection as feasible and warranted; such as, eliminating hazards, providing containment, and furnishing effective monitors and controls.

Facility capabilities and/or features which are needed for interim S\&M or the final decommissioning should be preserved as appropriate. The facility status after deactivation will be negotiated to the satisfaction of the receiving caretaker. The end points need to be practical, quantitative, clear, and achievable. While many end points should be identifiable during early planning, it is still an iterative process -- whereby decisions/agreements will have to be periodically re-visited as deactivation proceeds.

As a means of placing this $\mathrm{plan}$ and the prior statements into perspective, Figure A-1 and the following paragraphs offer a brief overview of the complete facility decommissioning process, including agreement on end-points, actual transition, long term maintenance \& surveillance, and final disposition and closure. Much of this process is out of scope for this plan. It is also possible that many of these steps could be consolidated or otherwise modified.

Assuming all possible missions for 340 have been exhausted, the operator will confer with $H Q$ regarding issuance of a formal shut-down order. This process could be delayed until 340 is $\mathrm{placed}$ in stand-by status, but a more proactive approach is assumed here.

Typically after receiving the HQ shut-down order the operating contractor opens negotiations with the Environmental Restoration (ER) contractor to establish End-Point Criteria (EPC) to meet ER acceptance requirements for receipt. The EPC document, along with a Transition Plan, serve to outline the functional steps/guidelines that must be pursued. These two documents are similar to the engineering study/functional design criteria phases of a capital project. The receiving organization may also wish to perform an assessment to characterize the program, compliance status, facility, state, and any other possible liabilities of completing a transfer.

Concurrent with the work on the EPC and Transition Plan, any necessary NEPA documentation is scheduled to begin. Currently a categorical exclusion is under development, although it is possible that an Environmental Assessment may be required.

A Project Management Plan is prepared, along with a long-term Surveillance and Maintenance Plan (SMP). The SMP outlines the scope of the caretaker that occurs between the end of deactivation and the initiation of final D\&D. This SMP is employed by the Project Hanford Management Contractor (PHMC) unt it formal transition to ER. It is possible that various capital upgrade packages will be identified to minimize long-term maintenance costs. A RCRA closure 
HNF-SD-LEF-SSP-001, Rev. 1

Figure A-1 Generic Decommissioning Process (compiled from Ecology, EPA, DOE, 1995)

Pre-decommissioning (largely the scope of this plan)

\begin{tabular}{|l|}
\hline Verify all future missions exhausted \\
\hline Initiate terminal clean-out \\
\hline HQ issues formal shut-down notice \\
\hline
\end{tabular}

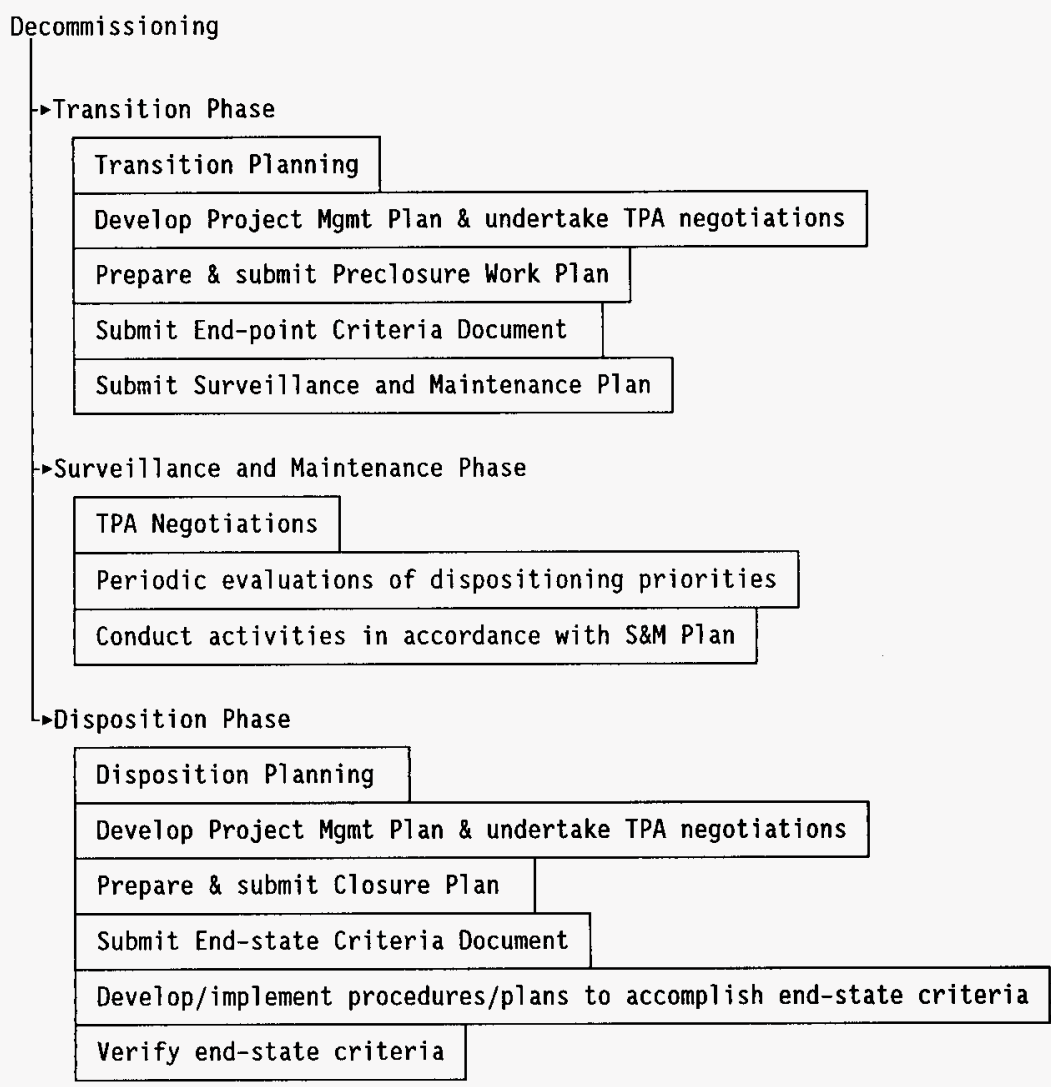




\section{HNF-SD-LEF-SSP-001, Rev. 1}

plan is prepared if needed. The land may revert to, and be covered under, one of existing 300 Area CERCLA operable units.

The deactivation is completed and any 340 inventories or residuals are either cleaned or left in place per agreements stated in the EPC. A Turn-over Package is prepared before the actual transition to ER is final. This package includes historical facility data, engineering documentation on operating systems, regulatory permits, TPA commitments, characterization data, configuration information, operating and deactivation $10 \mathrm{~g}$ books, property records, safety documents, equipment lists, material inventories, etc. (DOE 1995b). This deactivation plan is not intended to satisfy that need. 